\title{
Factors influencing the movements during the breeding season of a female booted eagle (Aquila pennata) tagged by satellite in central Catalonia (Spain)
}

\author{
Faktory ovplyvňujúce pohyb satelitne sledovanej samice orla malého (Aquila pennata) \\ počas hniezdnej sezóny v centrálnom Katalánsku (Španielsko)
}

\author{
Josep BOSCH, José Francisco CALVO, Ana BERMEJO \& Javier de la PUENTE
}

\begin{abstract}
Foraging movements during the breeding season are a poorly studied aspect of booted eagle behaviour. We have investigated the relationship between weather and other abiotic factors and foraging behaviour, and also resource use by a female booted eagle, tagged by satellite-GPS transmitter in central Catalonia, during summer 2012 and spring 2013. Generalized Linear Models (GLMs) revealed that the distance travelled from the nest was significantly related to temperature, but also to the time of day and the age of chicks. Temperature also had a significant positive influence on flight altitude and the latter on flight speed. The Resource Utilization Function (RUF) showed significant resource use in locations close to water (rivers and water bodies) and also in agricultural areas, preferably close to urban areas and rivers. On the other hand, unlike in other areas of Spain, the use of the edges between forest and agricultural areas and forest areas themselves showed negative coefficients with values not significant, perhaps related to changes in prey availability in the traditional hunting grounds.
\end{abstract}

\begin{abstract}
Abstrakt: Pohyb za potravou počas hniezdnej sezóny je slabo preskúmanou stránkou správania orla malého. Počas leta 2012 a jari 2013 sme študovali vzt’ah medzi počasím a inými abiotickými faktormi a potravným správaním, tiež využívanie zdrojov samicou orla malého, vybavenou satelitnou GPS vysielačkou v strednom Katalánsku. Zovšeobecnené lineárne modely (GLM) ukázali, že vzdialenost' samice od hniezda významne súvisela s teplotou, ale tiež s dennou dobou a vekom mlád’at. Teplota mala tiež významný pozitívny vplyv na výšku a rýchlost' letu. Funkcia využívania zdrojov (RUF) ukázala ich významné využivanie v lokalitách v blízkosti vôd (riek a vodných plôch) a pol’nohospodárskej krajine najmä v blízkosti zastavaných území a riek. Na druhej strane, na rozdiel od iných území v Španielsku, využívanie okrajov medzi lesom a pol'nohospodárskou krajinou a samotných lesov vykázalo štatisticky nevýznamné negatívne koeficienty, čo asi súvisí so zmenami v dostupnosti koristi na týchto tradičných loviskách.
\end{abstract}

Key words: booted eagle, foraging behaviour, satellite telemetry, weather

\begin{abstract}
$\overline{\text { Josep Bosch (corresponding author), }}$ Cra. de Navarcles, 43, E-08251 Santpedor (Barcelona), Spain. E-mail: jboschprat@hotmail.com.

José Francisco Calvo, Departamento de Ecología e Hidrología, Universidad de Murcia, Campus de Espinardo, E-30100 Murcia, Spain. E-mail: jfcalvo@um.es.

Ana Bermejo, Javier de la Puente, SEO/BirdLife, Área de Estudio y Seguimiento de Aves, C/. Melquíades Biencinto, 34, E28053 Madrid, Spain. E-mail: abermejo@seo.org; jdelapuente@seo.org.

Acknowledgements: GPS data from the eagle tagged were obtained as part of the project 'Migra' (www.migraciondeaves.org/en/) developed by SEO/BirdLife and funded by Spain Iberdrola Foundation. We also thank Oscar Valiente for providing us with data from the particular meteorological station, the Direcció General del Medi Natural de la Generalitat de Catalunya for granting permissions for capturing and marking the eagle. We are very grateful to J. M. Marzluff for his comments and the information provided on use of the 'ruf' function, and Toni Borrás for his useful comments on part of the text, which helped to improve the paper.
\end{abstract}

\section{Introduction}

Satellite tracking has been shown to be an effective and accurate tool for studying so far untreatable or insufficiently known aspects of the biology of birds, such as fidelity to territories, mortality, habitat use and the extent of their territories (see Meyburg et al. 2006, 2007,
Margalida et al. 2008, Hernández-Pliego et al. 2014, López-López et al. 2014, Pfeiffer \& Meyburg 2015, among many others). In order to study its migration, satellite telemetry was first used with the booted eagle Aquila pennata in 2006, when two adult females were marked in the community of Madrid for which data 


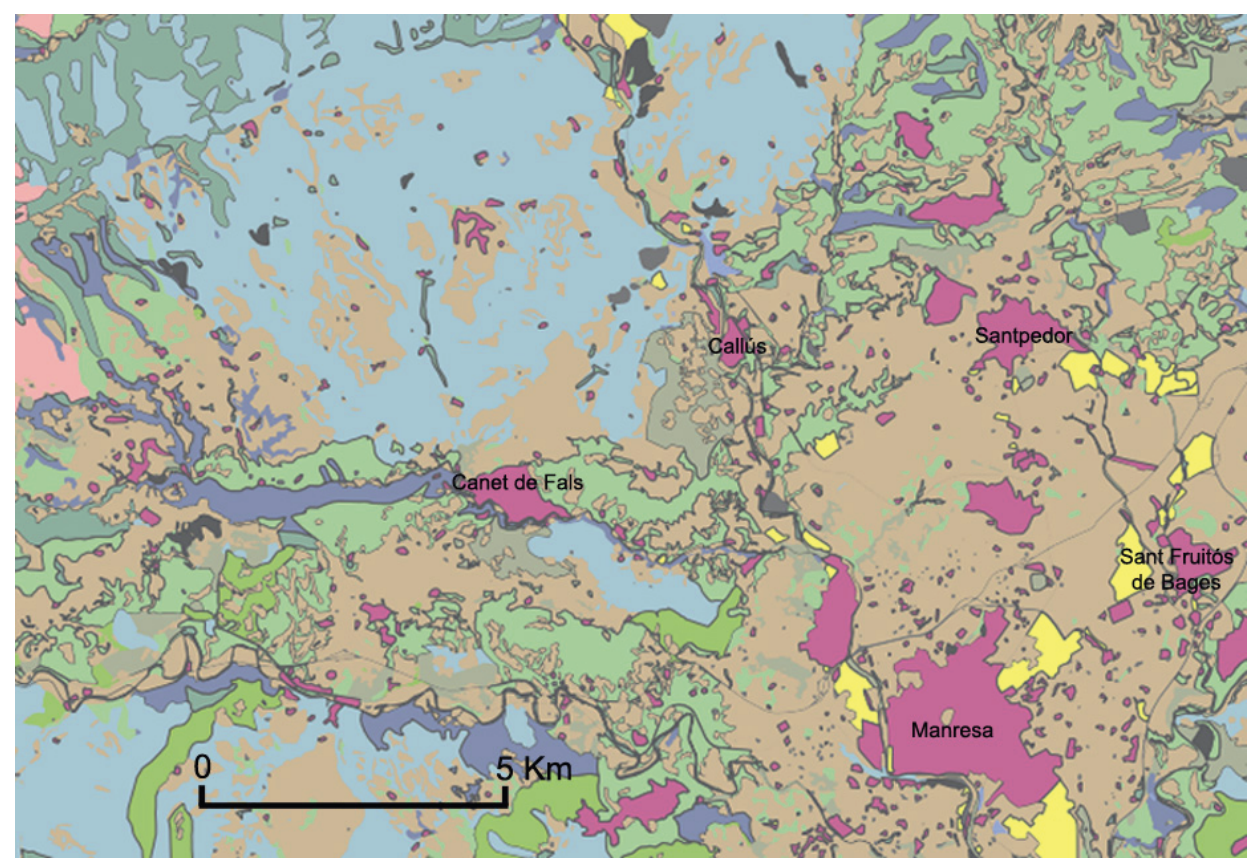

Fig. 1. Land use map and cover codes of study area.

Obr. 1. Mapa využívania krajiny a kódy pokryvu skúmaného územia.

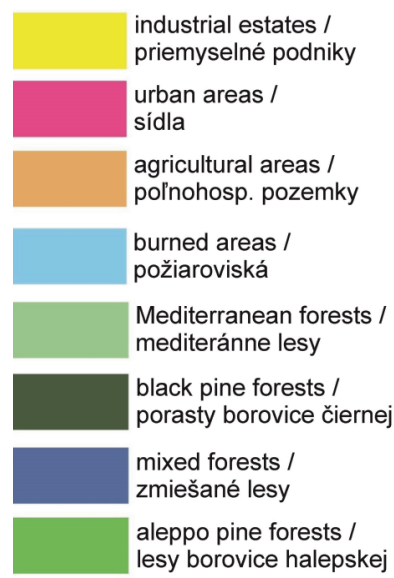

were received from their autumn migration and wintering in Mauritania and Mali respectively (Diaz \& Cebollada 2011). A year later, another eagle was tagged in France but now with a built-in GPS unit (Chevallier et al. 2010), which provided data for three years on five consecutive migratory journeys, with the wintering area in Nigeria. Later, they followed the eagles tagged with satellite and GSM GPS devices in Spain as part of the "Migra" project run by SEO/BirdLife (Mellone et al. 2014), in which the eagle of this study is included.

For the booted eagle, home range size and habitat use has been studied in the provinces of Murcia and Madrid using conventional VHF radio-tracking (Díaz 2006, Martinez et al. 2006, Díaz \& Cebollada 2011). More recently, a study on spatial ecology and habitat use by sixteen booted eagles satellite tagged in the "Migra" project (López-López et al. 2016), was developed in parallel and independently of this study. Undoubtedly, satellite tracking allows us to know more aspects and improve accuracy and reliability in the results on local movements and could be a good tool to help raptor managers improve the habitat management for conservation.

In this paper we present the results of the influence of meteorological factors on bird movements during the breeding season and resource use by an adult breeding female booted eagle, tagged by satellite in Central Catalonia in summer 2012.

\section{Material and methods}

S t u d y a r e a a n d b i r t a g g i n g This study was conducted in the Bages district (central Catalonia), located in the east of the Spanish Mediterranean region $\left(41^{\circ} 46^{\prime} \mathrm{N}, 1^{\circ} 44^{\prime} \mathrm{E}\right)$. The habitat consists of mountain forests which occupy $45 \%$ of the land, represented mainly by black pine (Pinus nigra) and also Aleppo pines (Pinus halepensis) in the sunniest areas facing south. These forests are interspersed with areas of scrub (17\%), dry cereal and other crops, such as almond (Prunus dulcis), olive groves (Olea europaea) and vineyards (Vitis vinifera) (33\%) (Fig.1). The climate is of sub-Mediterranean character with annual rainfall of $709 \mathrm{~mm}$ and 2480 hours of sunshine during the study period (Meteorological Service of Catalonia - SMC).

On July 8, 2012, an adult breeding female booted eagle was captured in the Natura 2000 Special Area of Conservation (SAC) "Serra de Castelltallat" (ES5110014), by means of a 'dho-gaza' net located about $100 \mathrm{~m}$ from the nest containing two chicks about 30 days old (Fig. 2 and 3). A live eagle owl (Bubo bubo) was used as a decoy. The eagle was tagged with a refurbished satellite transmitter of 22 gr Global Positioning System (GPS) Solar Argos 3D (Id. 68457) made by Microwave Telemetry Inc. (USA), attached as a backpack harness made of ribbon Teflon (Garcelon 1985, Kenward 2001) (Fig. 4). The transmitter was programmed to 

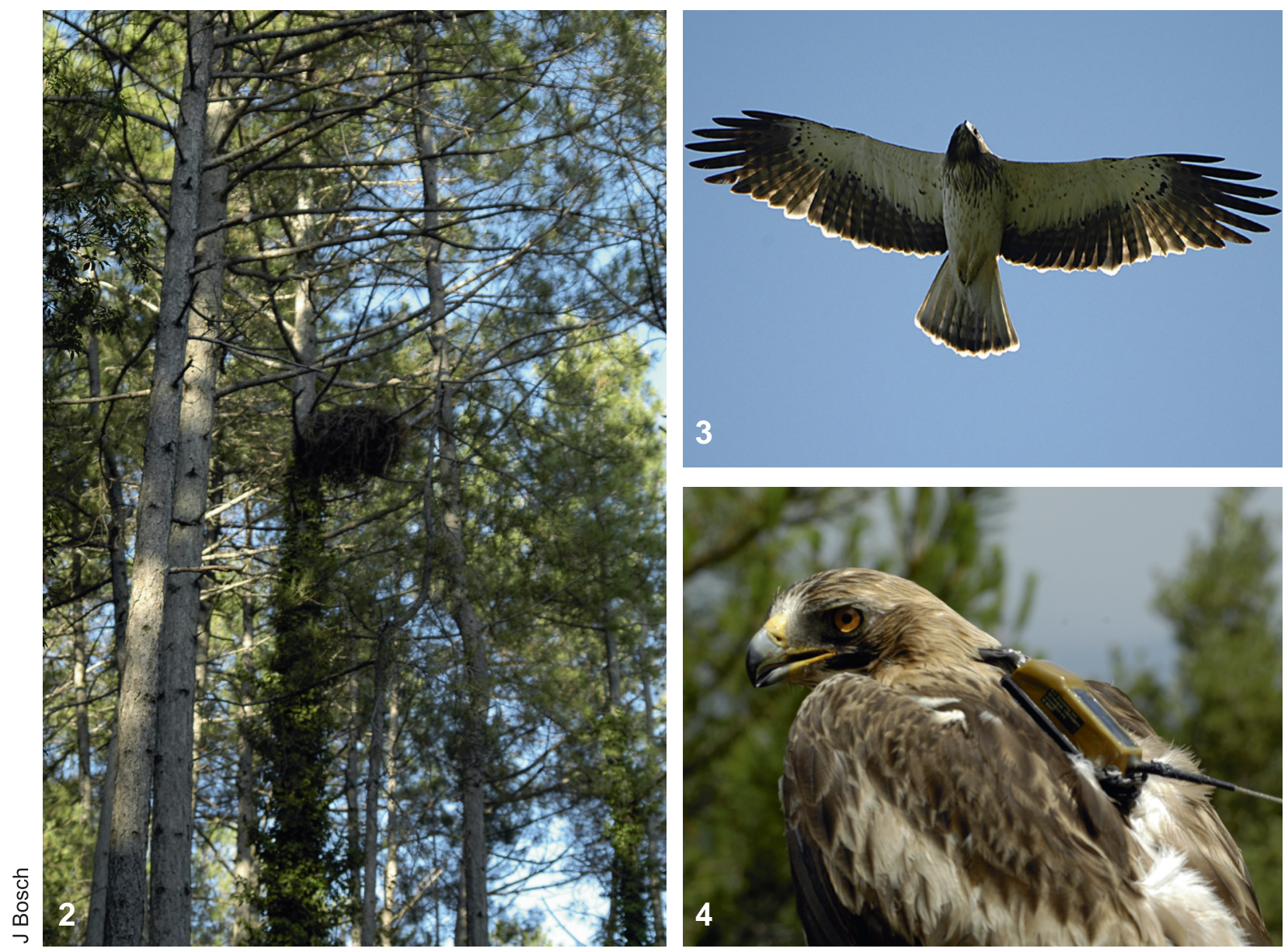

Fig. 2-4. Booted eagle nest in a black pine wood (2); female booted eagle soaring over nest site (3), and tagged by satellite transmitter just before being released (4).

Obr. 2 - 4. Hniezdo orla malého v poraste borovice čiernej (2); samica orla malého krúžiaca nad hniezdiskom (3) a so satelitnou vysielačkou pred vypustením (4).

emit GPS fixes every three hours, from 6:00 to 21:00 during the period from July 8 to August 14, 2012, and every hour from 6:00 to 20:00 from August 15 to September 19, 2012. In the spring of 2013, from March 30 until April 23, when the transmitter either dropped from the eagle's body or she tore it off, it issued fixes every hour from 6:00 to 20:00.

$\mathrm{H}$ o $\mathrm{me}$ ra n g e $\mathrm{s}$

The home ranges during the fledgling period (summer of 2012) and the pre-laying period (spring 2013) were calculated using Minimum Convex Polygon (MCP) and Kernel Utilization Distribution (KUD), including 95\% of fixes for each period and also with $100 \%$ of fixes to represent the area of maximum activity. The kernel method prevented the use of Least Square Cross Valida- tion (LSCV) with fixes to calculate the smoothing parameter. The use of LSCV minimizes the Mean Integrated Square Error (MISE) (i.e. the difference in volume between true Utilization Distribution (UD) and estimated UD). According to Seaman and Powell (1996), in some cases cross-validation criteria can not be minimized, and because this difficult problem has not been assessed by statistical theoreticians, no definitive answer is available as yet. The use of the reference bandwidth 'href' as smoothing parameter tends to over-smoothe the home range. Daily and weekly home ranges and maximum activity areas were also calculated using MCP (Tables 1 and 2). The home ranges were calculated using the adehabitatHR package (Calenge 2011) in R 3.2.4 Revised (R Core Team 2016). 
Tab. 1. Area of maximum weekly activity calculated using the Minimum Convex Polygon (MCP 100\%), home range weekly (MCP $95 \%)$, maximum distance and direction travelled from the nest by the female booted eagle tagged by satellite.

Tab. 1. Plocha maximálnej týždennej aktivity vypočítaná pomocou najmenšieho konvexného polygónu (MCP $100 \%$ ), týždenný domovský okrsok (MCP 95 \%), maximálna vzdialenost' a smer preletený z hniezda satelitne sledovanou samicou orla malého.

\begin{tabular}{lcrrrr}
\hline $\begin{array}{l}\text { week / } \\
\text { týždeň }\end{array}$ & $\begin{array}{l}\text { No of fixes / } \\
\text { N záznamov }\end{array}$ & MCP (100\%) (ha) & MCP (95\%) (ha) & $\begin{array}{l}\text { max. distance from the nest (m) / direction / } \\
\text { max. vzdialenost' od hniezda }\end{array}$ \\
\hline 28 & 29 & 4153.20 & 1355.69 & 15,517 & SE \\
29 & 21 & 5634.97 & 4892.79 & 16,147 & SE \\
30 & 17 & 5086.77 & 2978.98 & 17,973 & SE \\
31 & 34 & 3559.07 & 3517.81 & 17,150 & SE \\
32 & 17 & 2677.77 & 2671.37 & 17,160 & SE \\
33 & 69 & $14,478.04$ & $11,281.22$ & 18,430 & SE \\
34 & 104 & $32,549.34$ & $14,741.51$ & 26,361 & SW \\
\hline
\end{tabular}

Tab. 2. Area of maximum daily activity calculated using the Minimum Convex Polygon (MCP 100\%), home range daily (MCP 95\%), maximum distance and direction travelled from the nest by the female booted eagle tagged by satellite.

Tab. 2. Plocha maximálnej dennej aktivity vypočítaná pomocou najmenšieho konvexného polygónu (MCP 100 \%), denný domovský okrsok (MCP 95 \%), maximálna vzdialenost' a smer preletený z hniezda satelitne sledovanou samicou orla malého.

\begin{tabular}{|c|c|c|c|c|c|}
\hline $\begin{array}{l}\text { day } / \\
\text { deň }\end{array}$ & $\begin{array}{l}\text { № of fixes } / \\
\text { N záznamov }\end{array}$ & MCP (100\%) (ha) & MCP (95\%) (ha) & $\begin{array}{l}\text { max. distance from the nest }(\mathrm{m}) / \\
\text { max. vzdialenost' od hniezda }\end{array}$ & $\begin{array}{l}\text { direction / } \\
\text { smer }\end{array}$ \\
\hline August 15 & 14 & 3874.47 & 3411.07 & 17,297 & SE \\
\hline August 16 & 14 & 4993.11 & 4665.82 & 16,506 & SE \\
\hline August 18 & 12 & 3373.25 & 3233.62 & 17,085 & SE \\
\hline August 19 & 15 & 8950.34 & 7343.33 & 18,430 & SE \\
\hline August 20 & 15 & 6674.93 & 6674.30 & 19,339 & SE \\
\hline August 22 & 10 & 3861.51 & 3335.58 & 18,398 & SE \\
\hline August 23 & 11 & 5202.45 & 5095.91 & 16,609 & SE \\
\hline August 24 & 9 & 2767.56 & 2671.89 & 16,956 & SE \\
\hline August 25 & 7 & $14,987.10$ & $13,864.01$ & 26,361 & SW \\
\hline August 26 & 15 & 4868.83 & 4644.23 & 17,166 & SE \\
\hline August 27 & 12 & 3803.01 & 2528.79 & 16,977 & SE \\
\hline August 28 & 15 & 7965.74 & 6925.74 & 17,121 & SE \\
\hline
\end{tabular}

Influe nce of we a the r a n d other abiotic factors on fora g i n g e h a vio u r

Meteorological data were obtained from a private automatic weather station located within the home range (http://www.meteofals.com; 392991E, 4622077N, 400 m. a.s.1.), which recorded several meteorological variables every ten minutes. The independent variables selected were temperature (temp), relative humidity (wet), dew point (dew), atmospheric pressure (press), wind speed and direction (wind and dir), the amount of rain in the last minute (rain), heat index (heat), the age of chicks (age) and the time of day (time). Generalized Linear Models (GLMs) were used to test the influence of independent variables on the distance to the nest of each fix (Dobson 1983, McCullagh \& Nelder 1989).

The influence of meteorological variables and the distance to the nest on flight altitude at each fix was also tested. The influence of meteorological variables and flight altitude (alt) on the flight speed was also tested, using only the fixes indicating active flight (with records of speed, direction and altitude).

We used circular statistics to test the relation between flight direction and wind direction (Jammalamadaka \& SenGupta 2001), and assessed the homogeneity of these variables using the Watson test. We also assessed the angular dispersion using the Rayleigh test. These tests were computed using the 'CircStats' package (Agostinelli \& Lund 2012) in R software.

R e s o u c e u s e

Resource use was defined with five categorical variables using the criteria of land use codes of CORINE 2000: wetlands $(5.1 .1,5.1 .2$, rivers and water bodies in this case), urban habitat $(1.1 .1,1.2 .1$, cities, towns, industrial estates and urbanizations), agricultural areas (2.1.1, 2.2.1, 2.2.2, 2.2.3, 2.3.1.; dry lands, fruit trees, olive groves and pastures), edge areas (2.4.3., 2.4.4.; agro- 
Fig. 5. Routes and fixes (a) and Utilization Distribution (b) (excluding $1000 \mathrm{~m}$ around the nest) of tagged female booted eagle from July 8 to August 29, 2012 (nesting area $=$ blue triangle; core foraging area $=$ green square). For land use map color codes see Fig. 1.

Obr. 5. Trasy a pozície (a) a tzv. distribúcia využívania (b) (okrem 1000 m okruhu okolo hniezda) satelitne sledovanej samice orla malého od 8 . júla do 29. augusta 2012 (hniezdne územie = modrý trojuholník; jadro lovného teritória = zelený štvorec). Farebné kódy pokryvu mapy využitia krajiny sú na obr. 1 .
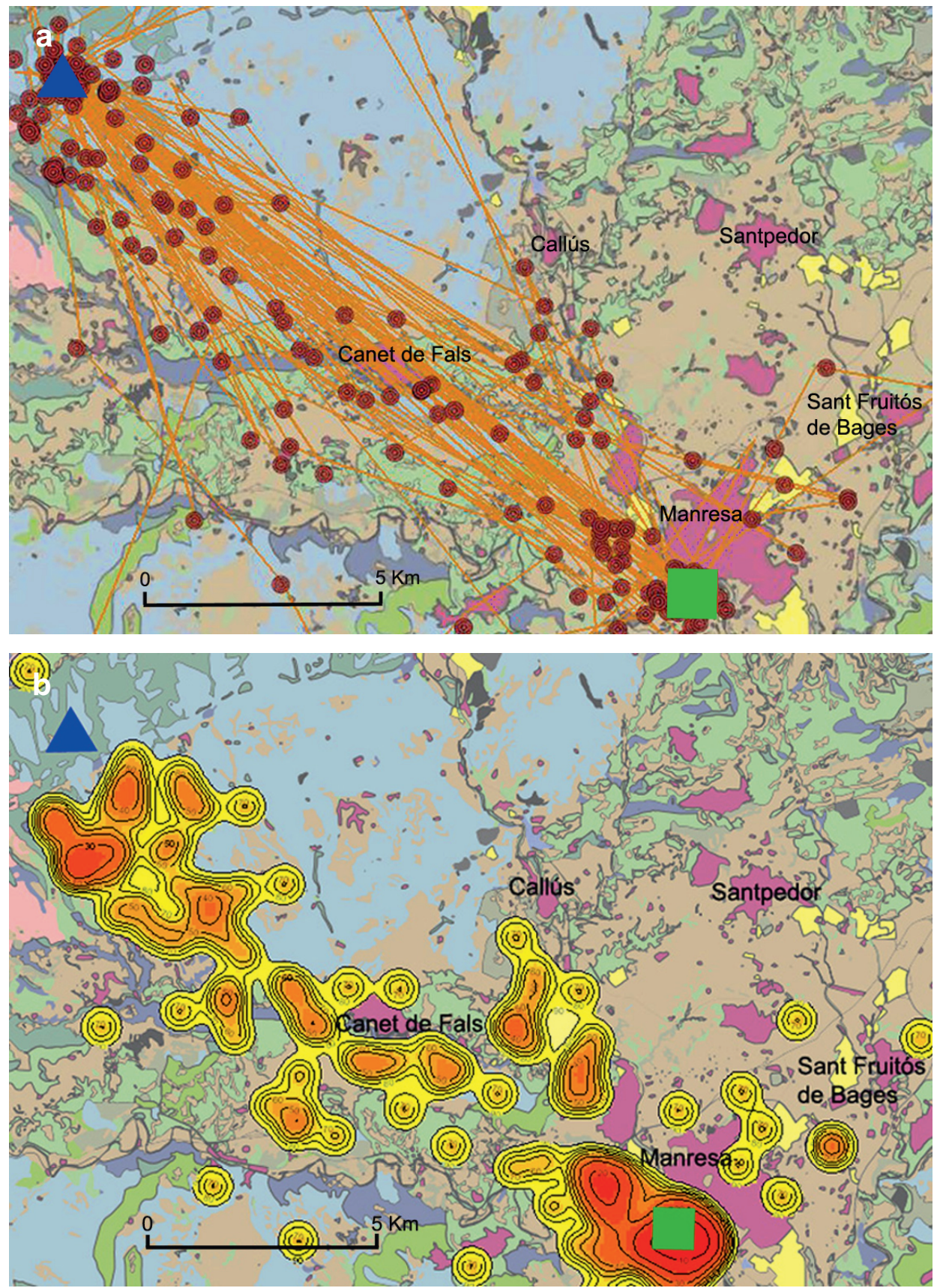

forestry and agricultural areas interspersed with forest areas) and forest areas (3.1.2., 3.2.3., 3.2.4.; coniferous forest and sclerophyllous vegetation and transition zones between forest and scrub). Moreover, three continuous variables were used: distance to the nest, distance to water and distance to urban areas. All the variables were assessed in each fix using the Google Earth software (satellite images updated on May 10,
2012), according to the land use definitions of CORINE 2000.

The use of space was evaluated based on the height of the Utilization Distribution (UD) at each fix. UD provides a three-dimensional extent of the use of space within the home range, where the height of the UD shows the probability of use in each square containing each of the fixes (Fig. 5). The UDs may be obtained 
Tab. 3. Estimates of GLM parameters on the distance from the nest $(A)$, flight altitude $(B)$ and flight speed $(C)$ of the booted eagle's female tagged by satellite.

Tab. 3. Odhady parametrov zovšeobecneného lineárneho modelu (GLM) pre vzdialenost' od hniezda (A), výšku letu (B) a rýchlost' letu (C) satelitne sledovanej samice orla malého.

Temperature = teplota vzduchu, age of chicks = vek mlád'at, time of day = denný čas, wind speed = rýchlost' vetra, flight altitude $=$ výška letu.

\begin{tabular}{lllll}
\hline A) & $\boldsymbol{\beta}$ & S.E. & $\mathbf{t}$ & $\mathbf{P}$ \\
\hline intercept & -0.237 & 0.618 & -0.383 & 0.7020 \\
temperature & 0.219 & 0.022 & 9.935 & $<0.0001$ \\
age of chicks & 0.042 & 0.007 & 6.264 & $<0.0001$ \\
time of day & -0.006 & 0.001 & -4.605 & $<0.0001$ \\
\hline
\end{tabular}

$\mathrm{AIC}=940.04, \mathrm{R}^{2}=0.43$, adjusted $\mathrm{R}^{2}=0.42$

$\mathrm{F}_{3,246}=60.49, \mathrm{P}=<0.0001$

\begin{tabular}{lrrrr}
\hline B) & \multicolumn{1}{c}{$\boldsymbol{\beta}$} & \multicolumn{1}{c}{ S.E. } & \multicolumn{1}{c}{$\mathbf{t}$} & $\mathbf{P}$ \\
\hline intercept & -337.093 & 210.949 & -1.598 & 0.1123 \\
temperature & 21.790 & 7.123 & 3.059 & 0.0027 \\
wind speed & 20.933 & 10.714 & 1.954 & 0.0527 \\
\hline Al
\end{tabular}

$\overline{\mathrm{AIC}}=2093.1, \mathrm{R}^{2}=0.11$, adjusted $\mathrm{R}^{2}=0.10$

$\mathrm{F}_{2,142}=8.84, \mathrm{P}=0.0002$

\begin{tabular}{lrlrl}
\hline $\mathbf{C})$ & $\boldsymbol{\beta}$ & S.E. & $\mathbf{t}$ & $\mathbf{P}$ \\
\hline intercept & 14.716 & 1.041 & 14.141 & $<0.0001$ \\
flight altitude & 0.009 & 0.002 & 4.772 & $<0.0001$ \\
\hline AlC
\end{tabular}

$\mathrm{AIC}=1022.3, \mathrm{R}^{2}=0.14$, adjusted $\mathrm{R}^{2}=0.13$

$\mathrm{F}_{1,143}=22.77, \mathrm{P}=<0.0001$

from fixes using kernel techniques (Worton 1989, Kernohan et al. 2001). With appropriate sample sizes (n $>50$ ), kernel methods have been shown to be better than other techniques for representing space use (Marzluff et al. 2004). This study used the kernel method by $\mathrm{h}$ smoothing parameter calculated by LSCV for the heights of the UD in each fix, with a grid size of $84 \times 84$ $\mathrm{m}$ and an extent of $99 \%$ kernel home range boundary (Marzluff et al. 2004, Kertson \& Marzluff 2009). The fixes included in a circle of $1000 \mathrm{~m}$ radius around the nest were excluded from the analysis because in this area the eagle usually sleeps, feeds and cares for the chicks, but does not go foraging or hunting. We also excluded the fixes obtained just before dawn and after dark. There were a total of 155 fixes taken between July 10 and August 29, 2012. The use of space was related to the use of resources by the Resource Utilization Function (RUF) (Handcook 2012). See also Marzluff et al. (2004) for more information. This function measures the probability of animal use of space based on the UD height at each fix. The results were also compared with the 86 existing observations of the species, taken between 2007 and 2015 by 21 ornithologists in the
Bages district during the breeding season, obtained from the website of the Catalan Ornithology Institute (ICO; http://www.ornitho.cat).

\section{D a t a a n a 1 y s i s}

Firstly, to identify possible cases of correlation between the independent variables of the GLM analysis, Spearman correlation tests were conducted between the eight meteorological variables, the age of the chicks and the time of day. There was high correlation between the temperature, the relative humidity and the heat index $\left(\mathrm{r}_{\mathrm{s}}\right.$ $>|0.86|)$. Consequently the last two variables were excluded from the GLM analysis. Distances were transformed logarithmically to avoid a biased distribution. The best GLM models were selected through comparison with ANOVA and by the minor value of the AIC.

The three continuous variables defined for the RUF were strongly correlated $\left(r_{s}>|0.86|\right)$. Thus, the distance from the nest and the distance to urban areas were excluded from the analysis following the criteria of the minor value of the Akaike Information Criterion (AIC), using the distance to water only in the RUF analysis.

All statistical analyses were performed with R 3.2.4 Revised (R Development Core Team 2016).

\section{Results}

During the summer of 2012, the transmitter provided 291 GPS fixes from July 8 until August 29, when the eagle began migration (Fig. 5). In the spring of 2013, it provided 77 GPS fixes from April 11 until April 23.

The approximate laying date in the 2012 season was April 30 and hatching date of the first chick June 6. For 2013 season, laying date was May 19 and hatching date June 25.

\section{H o m e $r$ a n g e}

The home range from July 8 to August 29, 2012 was 17,508 ha (MCP 95\%) and 25,255 ha (95\% KUD) and the area of maximum activity was 22,267 ha (MCP $100 \%$ ) and 25,601 ha ( $100 \%$ KUD).

The home ranges daily and weekly, as well as areas of maximum activity, maximum distances and directions travelled from the nest, are presented in Tables 1 and 2. The home range from the arrival of spring migration on April 11, until April 23, 2013 (when the transmitter was lost), was 414 ha (MCP 95\%) and 1958 ha (95\% KUD), and the area of maximum activity 653 ha (MCP 100\%) and 1958 ha (100\% KUD). 

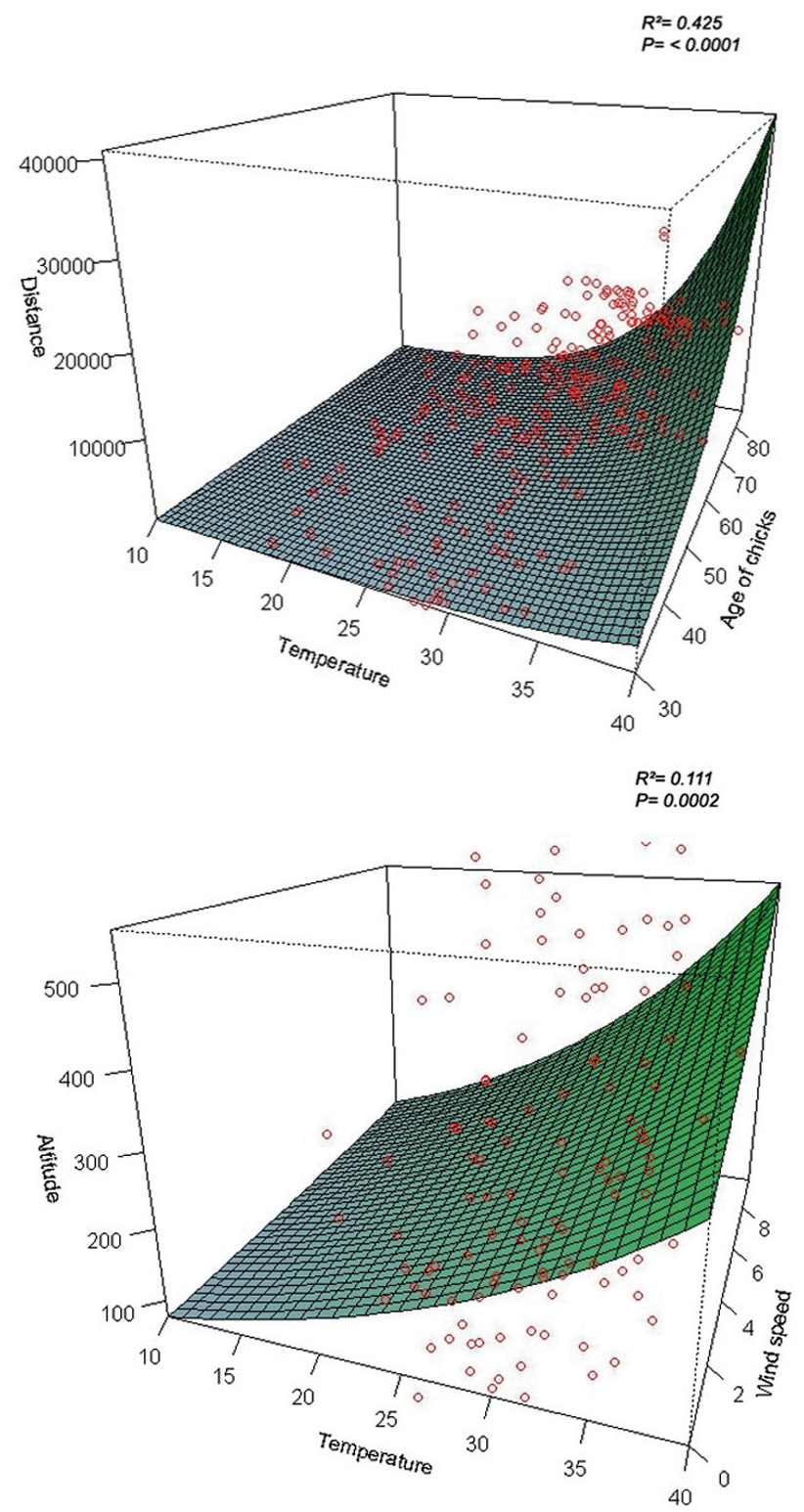

Fig. 6-7. Association among the distance travelled from the nest $(\mathrm{m})$ by the tagged booted eagle's female, air temperature $\left({ }^{\circ} \mathrm{C}\right)$ and the age of chicks (days) (6); and association among flight altitude (m) of tagged booted eagle's female, air temperature $\left({ }^{\circ} \mathrm{C}\right)$ and wind speed $(\mathrm{m} / \mathrm{s})(7)$.

Obr. 6 - 7. Vzt'ah medzi vzdialenost'ou od hniezda (distance; $\mathrm{m}$ ) sledovanej samice orla malého, teplotou vzduchu (temperature; ${ }^{\circ} \mathrm{C}$ ) a vekom mlád'at (age of chicks; dni) (6) a vzt'ah medzi výškou letu (altitude; m) sledovanej samice orla malého, teplotou vzduchu (temperature; ${ }^{\circ} \mathrm{C}$ ) a rýchlost'ou vetra (wind speed; m/s) (7).

I n f l u e e e f w e a the $\mathrm{r}$ a $\mathrm{nd}$ other abiotic factors on fora g i n g b e h a i o u r

The best GLM model indicates that temperature, age of chicks and time of day have a significant influence on the distance travelled from the nest (Table 3 and Fig. 6). Moreover, temperature had a significant positive influence on flight altitude, and wind speed was just above 


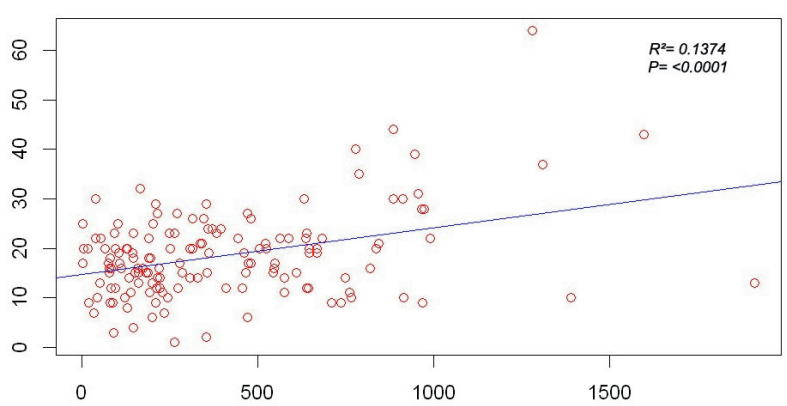

Fig. 8. Association between flight altitude $(\mathrm{m})$ of tagged booted eagle's female and flight speed (kph).

Obr. 8. Vzt’ah medzi výškou letu sledovanej samice orla malého $(\mathrm{m})$ a jeho rýchlost’ou $(\mathrm{km} / \mathrm{h})$.

the significance level of 0.05 (Table 3 and Fig. 7). When the eagle was foraging the average temperature was $30.38 \pm \mathrm{SD} 3.94{ }^{\circ} \mathrm{C}$ and the average flight altitude $406.94 \pm$ SD $340.51 \mathrm{~m}$ above ground level. The average flight speed was $18.50 \pm$ SD $8.69 \mathrm{kph}$. Flight speed was strongly influenced by flight altitude (Table 3 and Fig. 8 ). The average and maximum wind speeds were 13.18 $\pm \mathrm{SD} 9.43 \mathrm{kph}$ and $36.4 \mathrm{kph}$ respectively. The maximum gust speed was $62.6 \mathrm{kph}$.

The Watson test indicated significant differences between mean flight direction and mean wind direction $\left(\mathrm{U}^{2}=0.5137, \mathrm{P}=<0.001\right)$. Rayleigh's tests indicated a uniform angular distribution in flight direction pattern $(\rho=0.09, P>0.30)$ and concentration in wind direction $(\rho$ $=0.42, \mathrm{P}<0.001)$.

R e s o u r c e u s e

The area studied, excluding locations that were within a circle of $1000 \mathrm{~m}$ radius around the nest, comprises 8145 ha (Kernel LSCV 95\%) and 14,840 ha (MCP 95\%).

The RUF indicated a significant increase in the use of resources in the locations closest to water. Crops, preferably closer to urban areas and rivers, were used to a lesser extent. Contrary to expectations, the use of the edges between forests and agricultural areas and forest areas themselves showed slightly negative coefficients with values not significant (see Tables 4 and 5 and Fig. 9 and 10).

\section{Discussion}

$\mathrm{Hom}$ e $\mathrm{range} \mathrm{size}$

Until now, the few data available about the home range size of the booted eagle were obtained through conventional VHF radio tracking and by direct observation. In the region of Murcia, the home ranges thus obtained ranged from 8839 to 23,334 ha ( $95 \%$ KUD), with average values of $11,730 \pm \mathrm{SD} 3464$ ha $(\mathrm{n}=4)$ for females and 20,354 \pm SD 4214 ha $(\mathrm{n}=2)$ for males (Martinez et al. 2006). In Madrid (Sierra de Guadarrama) six females were tagged with average home range of 7318 ha (4200-10,590 ha) and two males with a home range of

Tab. 4. Standardized Resource Utilization Function (RUF) coefficients of the female booted eagle tagged by satellite.

Tab. 4. Koeficienty štandardizovanej funkcie využívania zdrojov (RUF) satelitne sledovanou samicou orla malého.

\begin{tabular}{|c|c|c|c|c|}
\hline $\begin{array}{l}\text { resource / } \\
\text { zdroj }\end{array}$ & $\begin{array}{l}\text { standardized } \beta / \\
\text { štandardiz. } \beta\end{array}$ & S.E. & $\begin{array}{l}95 \% \text { confidence interval } \\
95 \% \text { konfid. interval }\end{array}$ & $\mathbf{P}$ \\
\hline distance to water / vzdial. k vode & -0.537757 & 0.113872 & $-0.7628,-0.3127$ & $<0.001$ \\
\hline wetland habitat / mokrade & 0.548034 & 0.106642 & $0.3373,0.7588$ & $<0.001$ \\
\hline urban habitat / sídla & 0.114456 & 0.088987 & $-0.0613,0.2903$ & 0.203 \\
\hline agricultural areas / polia & 0.370219 & 0.172784 & $0.0288,0.7116$ & 0.034 \\
\hline edge areas / okraje & -0.08475 & 0.175837 & $-0.4322,0.2627$ & 0.631 \\
\hline forest areas / lesy & -0.037253 & 0.162728 & $-0.3588,0.2843$ & 0.819 \\
\hline
\end{tabular}

Tab. 5. Unstandardized Resource Utilization Function (RUF) coefficients of the female booted eagle tagged by satellite.

Tab. 5. Koeficienty neštandardizovanej funkcie využívania zdrojov (RUF) satelitne sledovanou samicou orla malého.

\begin{tabular}{|c|c|c|c|c|}
\hline $\begin{array}{l}\text { resource / } \\
\text { zdroj }\end{array}$ & $\begin{array}{l}\text { unstandardized } \beta \text { / } \\
\text { neštandardiz. } \beta\end{array}$ & S.E. & $\begin{array}{l}\text { LS estimate / } \\
\text { odhad najm. štvorcov }\end{array}$ & LS S.E. \\
\hline distance to water / vzdial. k vode & -0.778545 & 0.164860 & -0.886213 & 0.144 \\
\hline wetland habitat / mokrade & 2.469052 & 0.480455 & 2.763090 & 0.457 \\
\hline urban habitat / sídla & 0.426880 & 0.331889 & 3.521560 & 0.301 \\
\hline agricultural areas / polia & 0.760016 & 0.354706 & 0.823910 & 0.323 \\
\hline edge areas / okraje & -0.184915 & 0.383657 & -0.409175 & 0.350 \\
\hline forest areas / lesy & -0.093988 & 0.410557 & -0.322494 & 0.385 \\
\hline
\end{tabular}



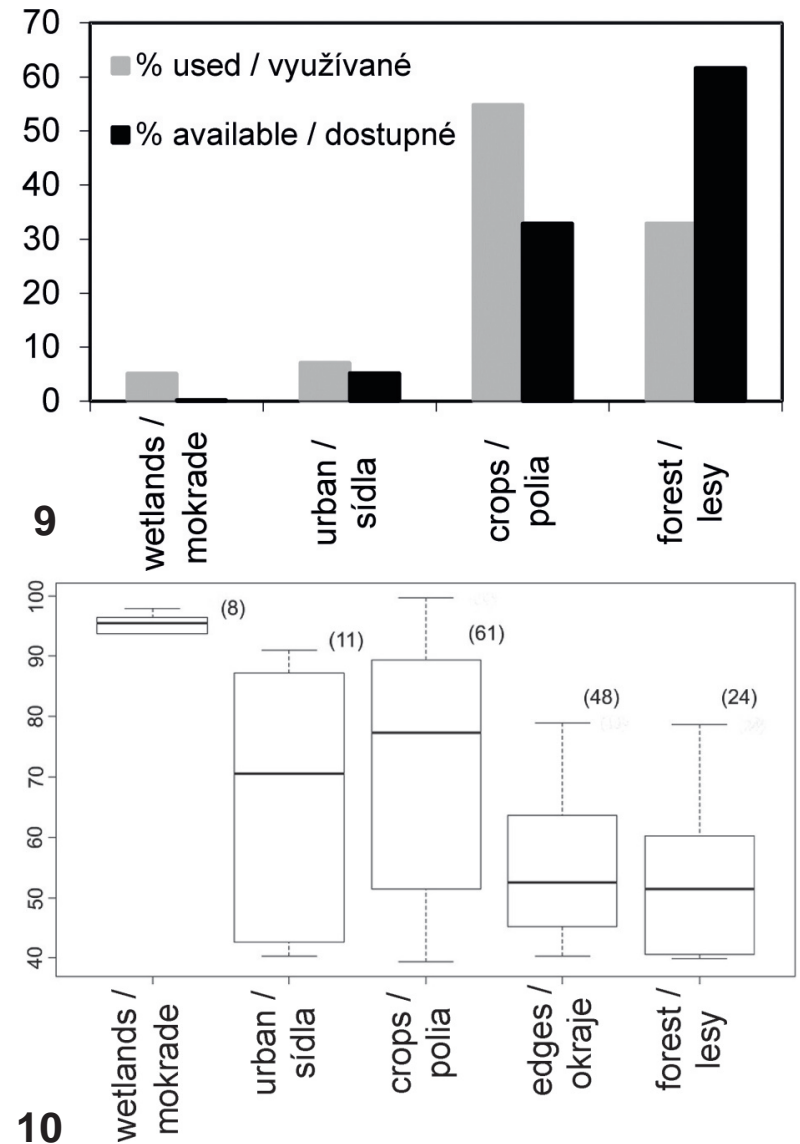

Fig. 9-10. Used and available habitat types within the home range of the tagged booted eagle's female (9). Relative resources utilization (\%) observed within the home range of the tagged booted eagle's female. The means were obtained by summing the heights of the Utilization Distribution (UD) (a measure of relative probability of use) in each $1 \times 1 \mathrm{~km}$ grid square, containing a recorded fix, for each type of land use ( $n$ in brackets) (10).

Obr. 9 - 10. Využívané a dostupné typy habitatov $v$ domovskom okrsku sledovanej samice orla malého (9). Relatívna miera využívania zdrojov (\%) zistená u sledovanej samice orla malého $v$ domovskom okrsku. Priemerné hodnoty boli získané zrátaním hodnôt výšok distribúcie využívania (UD) (miera relatívnej pravdepodobnosti využívania zdrojov) v každom štvorci $1 \times 1 \mathrm{~km}$ obsahujúcom pozíciu orlice pre každý typ využívania krajiny (n v zátvorkách) (10).

2805 ha (2000-3610 ha) (Díaz \& Cebollada 2011). In the Sierra de Guadarrama the home ranges of females were more extensive than those of males, because males foraged preferably at the bottom of the mountain, near the nest sites, while females travelled far away during the post-fledgling period (Díaz \& Cebollada 2011). In
Murcia the home range sizes of both sexes are greater than in Madrid, those of males being greater than for females. More recently, López-López et al. (2016) found that the median value of home ranges of sixteen booted eagles, tagged by satellite as part of the 'Migra' project, was more extensive than those mentioned before for Murcia and Madrid, and showed no significant differences between sexes. In the same way, for red kites (Milvus milvus) the home ranges obtained by direct observation and VHF radio tracking tend to be smaller than those obtained using GPS satellite technology, because these methods do not allow data to be obtained from flights further away from the nest (Pfeiffer \& Meyburg 2015). Home range sizes depend on many factors such as the availability of food, the quality and suitability of the habitat, intra- and inter-specific competition or how far away the food sources are from the nest (Newton 1979). In our case the home range was also much larger than those obtained in Murcia and Madrid by VHF radio-tracking. On the other hand, in the pre-laying period of the 2013 season, the home range was much smaller than during the summer of the previous year and were no records indicating movement. During the pre-laying period the activity of females are usually focused on reconstructing the nest, and they are fully provided with food by males (Newton 1979).

I $n \mathrm{fl}$ l u e n e of we a the r a n d other abiotic factors on fora g ing b e h a viou r

It is well known that the booted eagles, like other soaring raptors, use thermal uplifts to gain height and then move by gliding away using little effort and consequently little energy consumption. Thus the eagle in this study travelled preferably when the prevailing weather conditions were more favourable, air temperature being the main influencing factor. The model also showed that the time of day had a significant effect on the distance travelled from the nest, perhaps related to the fall in the ambient temperature in the late hours of day. On the other hand, the distances travelled from the nest rose significantly with increasing age of the chicks. In Madrid, Díaz \& Cebollada (2011) found that as soon as the chicks left the nest, the females became more independent and travelled further away from their nesting territories $(60-120 \mathrm{~km})$, sometimes for several days, exploring other natural or cultivated areas where potential prey was abundant. This behaviour suggests that by 

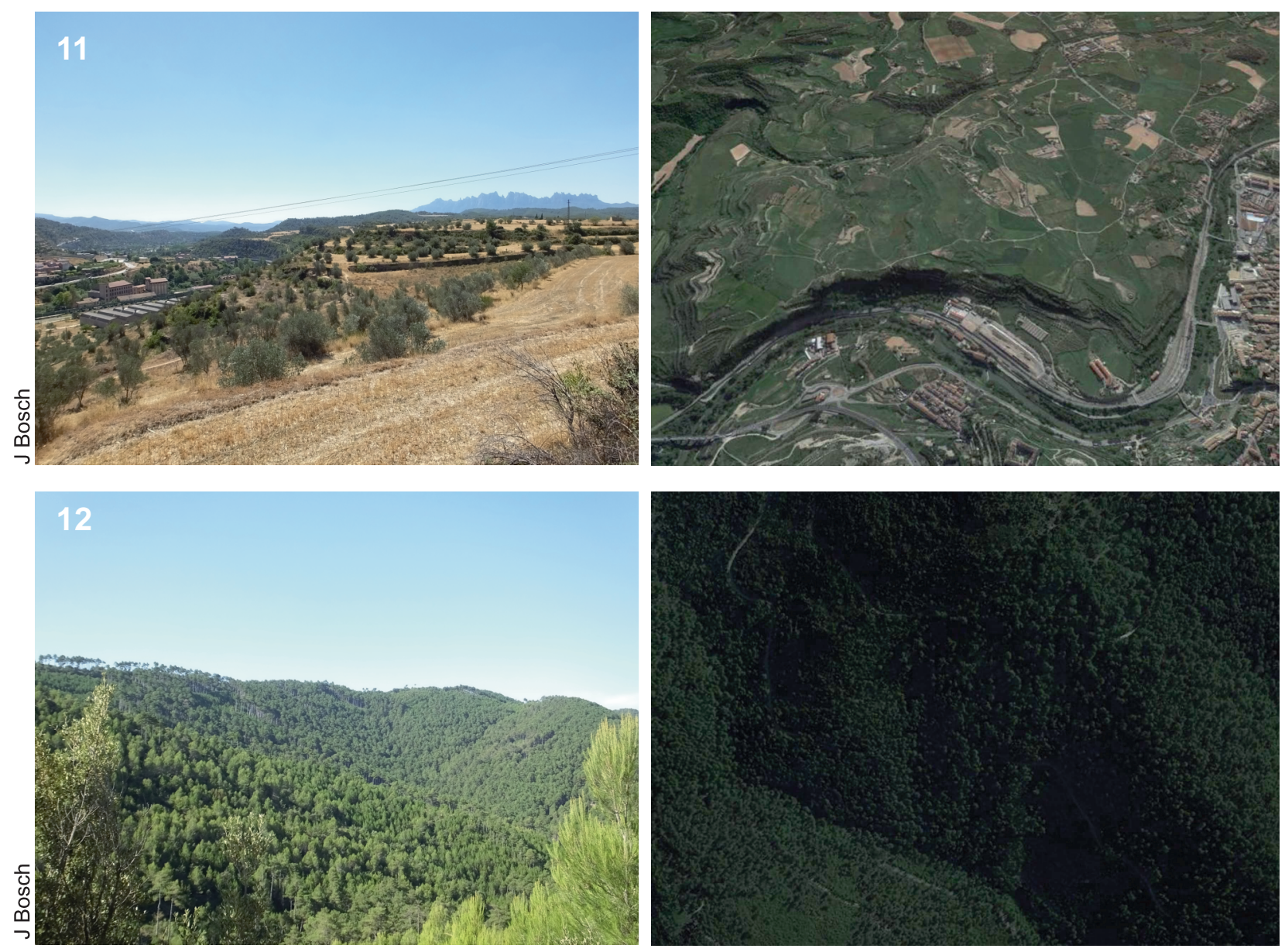

Fig. 11-12. Foraging core area of the tagged booted eagle (left); Google Earth image (right) (11). Nesting area of the tagged booted eagle (left); Google Earth image (right) (12).

Obr. 11 - 12. Jadro lovného teritória sledovanej samice orla malého (vlavo); snímka z Google Earth (vpravo) (11). Hniezdne územie sledovanej samice orla malého (vlavo); snímka z Google Earth (vpravo) (12).

that time females are more interested in obtaining food for themselves than providing for the chicks, in order to accumulate reserves before starting the migration. The migrant eagles and other soaring raptor species probably accumulate reserves before starting the migration to avoid having to forage during the migratory journey (Pannucio et al. 2006). In our case, from mid July the tagged eagle became more independent, sleeping some nights away from the nest $(1.15-9.79 \mathrm{~km})$ and travelling almost every day to the foraging core area, located $17 \mathrm{~km} \mathrm{SE}$ from the nest site, around the city of Manresa (Fig. 11), perhaps also favoured for the progressive increase in average temperatures. On August 29, 2012 the migration started, leaving the male alone with the two chicks, which did not leave the breeding area until about three weeks later, between September 16 to 23 (Fig. 12). All booted eagles of both sexes, tagged by satellite as part of the 'Migra' project, also perform long distance movements $(>20 \mathrm{~km})$ from the nest throughout the breeding season. This fact suggests that this is a common feature of this species (López-López et al. 2016).

Generally the study of the effects of wind on bird flight have been focused on migratory species (Liechti 2006), as is the case of the booted eagle (Mellone et al. 2013, 2014), but until now this phenomenon has been overlooked in connection with foraging movements. Recently, a study of the effects of wind on foraging trips by the lesser kestrel (Falco naumanni) suggests an absence of flight limitation caused by wind speed, prob- 
ably explained by the relatively weak winds blowing during the study period (approximately $9 \mathrm{kph}$ in the upper 25 percentile) (Hernández-Pliego et al. 2014). Wind is not a problem for land birds during foraging so long as it does not blow strongly. In contrast, strong winds may delay or completely prevent hunting (Elkins 2004). Our results show that wind intensity was insufficient to affect the foraging flights. Although the main trips from the nest to the core foraging area and the returns to the nest were directed SE-NW respectively, the results show uniformity in flight direction because the foraging movements were multidirectional.

R e s o u r e u s e

In the regions of Murcia and Madrid, the booted eagles tagged by VHF radio-tracking went looking for food preferably in the field margins and agro-forestry areas. The length of the margins and the extension of the dryland crops were good indicators of the abundance of this species (Sánchez-Zapata \& Calvo 1999, Díaz 2006, Martínez et al. 2006). Recently, the data from the sixteen booted eagles satellite tagged as part of the 'Migra' project showed the same preferences for foraging (LópezLópez et al. 2016). In Catalonia, the results of the Catalan Breeding Bird Atlas 1999-2002 (Estrada et al. 2004) also showed the importance of dry cereal and other crops in the use of the habitat, which represented 31 $\%$ of the grid squares of $1 \times 1 \mathrm{~km}$ where the species were detected, with indexes of positive selection $(0.25-0.40)$. In contrast, wetlands and urban and suburban habitats represented less than $1 \%$ of the grid squares, with negative values of indexes of selection (-1).

Contrary to expectations, the Resource Utilization Function (RUF) showed that the habitats preferred by our eagle were in areas close to rivers and agricultural landscapes, preferably close to urban areas. The use of margins between forest and agricultural areas and forest areas themselves outside of the nesting area was not significant, with slightly negative coefficients (see Table 4 and Fig. 5). In accordance with this, 86 direct observations of untagged eagles, taken from 2007 to 2015 throughout the breeding season in the Bages district by 21 different observers, showed that $52 \%$ of these observations were made in wet areas (rivers, water bodies and wetlands), $22 \%$ in urban and periurban areas, while the agricultural areas, the field margins and forest areas suffered a sharp decline compared with the results in the Atlas (Estrada et al. 2004), accounting together for only $25.5 \%$. However, the data of the wetlands may be strongly biased, because they were not taken with standardized methods (e.g. timed censuses in different habitats as used in the Atlas) and birdwatchers tend to visit these sites more frequently, due to their greater biodiversity and greater possibilities of seeing more species in a shorter period of time. Nevertheless, this does not detract from the fact that some eagles prefer these habitats for foraging and hunting. The use of urban habitats, open suburban zones and river habitats has been previously described in France and was attributed to changes in prey availability, such as the expansion of the Eurasian collared-dove (Streptopelia decaocto) and the degradation of traditional agro-forestry habitats, where the bird populations have suffered marked qualitative and quantitative decline, which has also affected the spring and autumnal migratory birds (Carlon 1996). Later, similar behaviour for the species was described in five cities of the self-governing region of Madrid, near Sierra de Guadarrama, in the period 2001-2003 (Palomino \& Carrascal 2007). The changes in the foraging behaviour of some booted eagles could be induced by changes in the abundance and distribution of prey species. During recent decades a general decline in occurrence of common birds has been detected in Spain and also generally in Europe, which has been attributed to changes in agricultural management, promoted by the common agricultural policy (CAP) with intensification, increased mechanization, elimination of hedges, increase in crops of rapid growth and massive use of agrochemicals (Ruiz Pérez 1990, Escandell 2013, Morales et al. 2013, Inger et al. 2014) and also induced by climate change (Newton 2013, Stephens et al. 2016). At the same time, the consumption of herbicides in Spain rose by $61 \%$ from 1995 to 2010 (http://servicios2.marm.es/sia/indicadores/ind/ficha.jsp?cod_indicador $=23 \&$ factor $=$ presion).

On the other hand, in our study area and in the whole of Catalonia, some bird species which are potential prey for the booted eagle have strongly increased. As in France, the Eurasian collared-dove population sharply increased from the early 90s to early 2000 (Pocino et al. 2005). The wood pigeon (Columba palumbus) has colonised urban and periurban zones, breeding in housing estates and urban parks (Larruy \& Burgas 2004, own data) and feral pigeons (Columba livia) have risen sharply in the cities and have also colonized other urban areas which were previously not inhabited (Sol 2004, own data). Other species, such as the common starling (Sturnus vulgaris), black starling (Sturnus unicolor) and 
magpie (Pica pica) have had slight to moderate increases or have remained stable in these habitats. Moreover, from the second half of the 1980s the populations of mallard (Anas platyrhynchos) in the Llobregat river basin and associated marshes have increased by approximately $93 \%$, due to protection of wetlands and compliance with the requirements of water quality of ECC water directives (Ferrer 2004, own data).

It is well known that birds form an important part of the diet of booted eagles in Mediterranean environments (Martinez \& Calvo 2005, Garcia Dios 2006, author's unpublished data), which are also characterized by their flexibility in prey selection (Casado et al. 2008) and show a great capacity for adaptation to environmental changes (Suarez et al. 2000). These facts and the trends in bird populations described above could explain the changes in the foraging behaviour of some booted eagles. To obtain food in these new habitats could be more feasible and energetically favourable for the eagles, as is the case of our eagle, especially when there is an abundance of young and inexperienced mediumsized birds of the prey species, than in the traditional hunting grounds, although she had to move a greater distance from the nest to hunt them.

M a n a g e m e $\mathrm{nt}$ i m p li c a t i o n s

Protection of the Special Conservation Areas and other sites of the Natura 2000 network has had a positive effect on maintaining the quality of the forested areas where booted eagles and other forest-dwelling raptors breed. However, the papers published so far have underlined the importance of agricultural zones, mostly outside the protected areas, for foraging and hunting activities (Sánchez-Zapata \& Calvo 1999, Díaz 2006, Martínez et al. 2006, López-López et al. 2016). Biodiversity conservation in the agricultural zones depends strongly on the Common Agricultural Policy (CAP). With the tool of agricultural subsidies, which today account for nearly half of the total budget of the European Union, the CAP must include the conservation of ecotones, agro-forestry mosaics and other agricultural activities clearly beneficial to wildlife (Telleria 2004). The last reform of the CAP, also named greening, which came into force in the autumn of 2014, subsidizes agricultural practices beneficial to the environment, such as crop diversification, maintenance of permanent pastures and areas of ecological interest within the agricultural areas. If the European Commission wants to effectively conserve biodiversity, the CAP must be revised with re- gard to dry cereal crops and also the application of agrochemicals, introducing restrictions to non-selective ones and banning the most toxic and persistent in the environment. Most of these agrochemicals strongly reduce the availability of food throughout the food chain, with important effects on bird populations (Newton 2013) and some are also hazardous to human health (Benitez-Leite et al. 2009, Guyton et al. 2015).

\section{References}

Agostinelli C \& Lund U 2012: CircStats: Circular Statistics, from "Topics in circular Statistics" (2001). $\mathrm{R}$ package. Retrieved March 25, 2016 from https://cran.r-project.org/web/packages/CircStats/index.html

Benítez-Leite S, Macchi ML \& Acosta M 2009: Congenital malformations associated to agrotoxics. Pediatrics files of Uruguay 80: 237-247. [In Spanish with English summary]

Calenge C 2011: Home range estimation in R: the adehabitatHR package. $\mathrm{R}$ package version 3.1.2. $\mathrm{R}$ Foundation for Statistical Computing, Vienna, Austria. Retrieved January 25, 2015 from https://cran.rproject.org/web/packages/adehabitatHR/index.html

Carlon J 1996: Response of booted eagles to human disturbance. British Birds 89: 267-274.

Casado E, Suárez-Seoane S, Lamelin J \& Ferrer M 2008: The regulation of brood reduction in booted eagles (Hieraaetus pennatus) through habitat heterogeneity. Ibis 150 : 788-798. DOI: $10.1111 / \mathrm{j} .1474-$ 919X.2008.00862.x

Chevallier D, Jiguet F, Nore T, Baillon F \& Cavallin P 2010: Satellite tracking of a booted eagle (Aquila pennata) during migration. Ringing \& Migration 25: 62-64.

Díaz J 2006: El águila calzada y su conservación en la Comunidad de Madrid [The booted eagle and its conservation in the community of Madrid]. FICAS, Madrid, 64. [In Spanish]

Díaz J \& Cebollada F 2011: Monitoring and conservation of booted eagle (Aquila pennata) in the Sierra de Guadarrama (Central Spain), 70-80. In Zuberogoitia I \& Martínez JE (eds), Ecology and conservation of European forest-dwelling raptors. Diputación Foral de Bizkaia. Bilbao, 407.

Dobson AJ 1983: Introduction to statistical modelling. Chapman \& Hall, London, 125.

Elkins N 2004: Weather and bird behaviour. Poyser. London, 280. 
Escandell V 2013: Sacre programme. Bird trends in spring, 4-9. In: SEO/BirdLife (ed.), SEO/BirdLife bird monitoring programmess in 2012, SEO/BirdLife, Madrid, 36.

Estrada J, Pedrocchi V, Brotons L \& Herrando S (eds) 2004. Catalan breeding bird atlas 1999-2002. Catalan Institute of Ornithology (ICO)/Lynx Edicions, Barcelona, 638.

Ferrer X 2004: Mallard (Anas platyrhynchos), 94-95. In: Estrada J, Pedrocchi V, Brotons L \& Herrando S (eds), Catalan breeding bird atlas 1999-2002. Catalan Institute of Ornithology (ICO)/Lynx Edicions, Barcelona, 638.

Garcelon DK 1985: Mounting backpack telemetry packages on bald eagles. Institute for Birdlife Studies, Arcata, California, 2.

García Dios IS 2006: Diet of the booted eagle (Hieraaetus pennatus) in the south of Avila: Importance of the songbirds. Ardeola 53: 39-54. [In Spanish with English summary]

Guyton KZ, Loomis D, Grosse Y, El Ghissassi F, Benbrahim-Tallaa L, Guha N, Scacianti C, Mattock H \& Straif K 2015: Carcinogenicity of tetrachlorrinphos, parathion, malathion, diazinon, and glyphosate. The Lancet Oncology 16: 490-491. DOI: 10.1016/S1470-2045(15)70134-8

Handcock MS 2012: Estimates of the resource utilization function. Version 1.5-2. Retrieved January 18, 2015 from http://www.stat.ucla.edu/ handcock/ruf/.

Hernández-Pliego J, Rodríguez C \& Bustamante J 2014: Gone with the wind: Seasonal trends in foraging movement directions for a central-place forager. Current Zoology 60 (5): 604-615. DOI: 10.1093/czoolo/60.5.604

Inger R, Gregory R, Duffy JP, Stott I, Voříšek P \& Gaston KJ 2014: Common European birds are declining rapidly while less abundant species' numbers are rising. Ecology Letters 18: 28-36. DOI: 10.1111/ele.12387.

Jammalamadaka SR \& SenGupta A 2001: Topics in circular statistics. World Scientific Press, Singapore, 336.

Kenward RE 2001: A manual for wildlife radio tagging. Academic Press, London, 311.

Kernohan BJ, Gitzen RA \& Millspaugh JJ 2001: Analysis of animal space use and movements, 125-166. In: Millspaugh JJ \& Marzluf JM (eds), Radio-tracking and animal populations. Academic Press, San Diego, California, USA, 474.
Kertson BN \& Marzluff JM 2009: Animal movement, home range, and resource utilization function (ruf) analysis in ArcMap 9.3. School of Forest Resources, University of Washington, Seattle, Washington, USA, 30.

Larruy X \& Burgas D 2004: Woodpigeon (Columba palumbus), 264-265. In: Estrada J, Pedrocchi V, Brotons L \& Herrando S (eds), Catalan breeding bird atlas 1999-2002. Catalan Institute of Ornithology (ICO)/Lynx Edicions, Barcelona, 638.

Liechti F 2006: Birds: blowin' by the wind? Journal of Ornithology 147: 202-211. DOI: 10.1007/s10336006-0061-9

López-López P, García-Ripollés C \& Urios V 2014: Food predictability determines space use of endangered vultures: implications for management of supplementary feeding. Ecological Applications 24: 938-949. DOI: $10.1890 / 13-2000.1$

López-López P, De la Puente J, Mellone U, Bermejo A \& Urios V 2016: Spatial ecology and habitat use of adult booted eagles (Aquila pennata) during the breeding season: implications for conservation. Journal of Ornithology DOI: 10.1007/s10336-0161357-z.

Martínez JE \& Calvo JF 2005: Prey partitioning between mates in breeding booted eagles (Hieraaetus pennatus). Journal of Raptor Research 39: 159-163.

Martínez JE, Pagán I, Palazón JA \& Calvo JF 2007: Habitat use of booted eagles (Hieraaetus pennatus) in a Special Protection Area: implications for conservation. Biodiversity \& Conservation 16: 3481-3488. DOI: 10.1007/s10531-006-9053-6

Margalida A, Heredia R, Razin M \& Hernández M 2008: Sources of variation in mortality of the bearded vulture (Gypaetus barbatus) in Europe. Bird Conservation International 18: 1-10.

Marzluff JM, Millspaugh JJ, Hurvitz P \& Handcock MS 2004: Relating resources to a probabilistic measure of space use: Forest fragments and Steller's jays. Ecology 85: 1411-1427. DOI: 10.1890/03-0114

McCullagh P \& Nelder JA 1989: Generalised linear modelling. Chapman \& Hall, London, 532.

Mellone U, De La Puente J, López-López P, Limiñana R, Bermejo A \& Urios V 2013: Migration routes and wintering areas of booted eagles (Aquila pennata) breeding in Spain. Bird Study 60: 409-413. DOI: 10.1080/00063657.2013.781113

Mellone U, De La Puente J, López-López P, Limiñana 
R, Bermejo A \& Urios V 2014: Seasonal differences in migration patterns of a soaring bird in relation to environmental conditions: a multi-scale approach. Behavioral Ecology \& Sociobiology 69: 75-82. DOI: $10.1007 / \mathrm{s} 00265-014-1818-4$.

Meyburg B-U, Meyburg C, Matthes J \& Matthes H 2006: GPS satellite tracking of lesser spotted eagles (Aquila pomarina): home range and territorial behaviour. Vogelwelt 127: 127-144.

Meyburg B-U, Meyburg C \& Franck-Neumann F 2007: Why do female lesser spotted eagles (Aquila pomarina) visit strange nests remote from their own? Journal of Ornithology 148: 157-166. DOI: 10.1007/s10336-006-0113-1

Morales MB, Guerrero I \& Oñate JJ 2013: Effects of agricultural management on birds breeding in cereal cultures: a multi-scale process. Ecosystems 22: 25-29. [In Spanish with English summary]

Newton I 1979: Population ecology of raptors. T \& A.D. Poyser, Berkhamsted, 399.

Newton I 2013: Bird Populations. The New Naturalist Library. Harper Collins, London, 596.

Panuccio M, Agostini N, Wilson S, Lucia G, AshtonBooth J, Chiatante G, Mellone U \& Todisco S 2006: Does the honey-buzzard feed during migration? British Birds 99: 367-368.

Palomino D \& Carrascal LM 2007: Habitat associations of a raptor community in a mosaic landscape of Central Spain under urban development. Landscape and Urban Planning 83: 268-274.

Pfeiffer T \& Meyburg B-U 2015: GPS tracking of red kites (Milvus milvus) reveals fledgling number is negatively correlated with home range size. Journal of Ornithology 156: 963-975. DOI: 10.1007/s10336-015-1230-5.

Pocino N, Giralt N \& Ferrer X 2005: Colonization and expansion of the collared dove (Streptopelia decaocto) in Catalonia. Catalan Journal of Ornithology 21: $1-10$.

R Core Team 2016: R: A language and environment for statistical computing. R Foundation for Statistical Computing, Vienna, Austria. Retrieved March 28, 2016 from http://www.R-project.org/.

Ruiz Pérez M 1990: Development of Mediterranean agriculture: an ecological approach. Landscape and Urban Planning 8: 211-220.

Sánchez-Zapata JA \& Calvo JF 1999: Raptor distribution in relationto landscape composition in semi-arid Mediterranean habitats. Journal of Applied Ecology 36: 254-262.

Seaman DE \& Powell RA 1996: An evaluation of the accuracy of kernel density estimators for home range analysis. Ecology 77: 2075-2085.

Sol D 2004: Rock dove (Columba livia), 260-261. In: Estrada J, Pedrocchi V, Brotons L \& Herrando S (eds), Catalan Breeding Bird Atlas 1999-2002. Catalan Institute of Ornithology (ICO)/Lynx Edicions, Barcelona, 638.

Stephens PA, Mason LR, Green RE, Gregory RD, Sauer JR, Alison J, Aunins A, Brotons L, Butchart SHM, Campedelli T, Chodkiewicz T, Chylarecki P, Crowe O, Elts J, Escandell V, Foppen RPB, Heldbjerg H, Herrando S, Husby M, Jiguet F, Lehikoinen A, Lindström Å, Noble DG, Paquet J-Y, Reif J, Sattler T, Szép T, Teufelbauer N, Trautmann S, Van Strien AJ, Van Turnhout CAM, Vorisek P \& Willis SG 2016: Consistent response of bird populations to climate change on two continents. Science 352: 84-87. DOI: $10.1126 /$ science.aac 4858

Suárez S, Balbontín J \& Ferrer M 2000: Nesting habitat selection by booted eagles (Hieraaetus pennatus) and implications for management. Journal of Applied Ecology 37: 215-223.

Telleria JL 2004: La ornitología hoy: Homenaje al Profesor Francisco Bernis Madrazo [Ornithology today: Tribute to Francisco Bernis Madrazo]. Editorial Complutense, Madrid, 291. [In Spanish]

Worton BJ 1989: Kernel methods for estimating the utilization distribution in home range studies. Ecology 70: 164-168. 